\title{
Photographic Feature
}

\section{Subsidence caused by gypsum dissolution at Ripon, North Yorkshire}

\author{
Anthony H. Cooper ${ }^{1}$ and Antony C. Waltham ${ }^{2}$ \\ ${ }^{1}$ British Geological Survey, Keyworth, Nottingham, NG12 5GG, UK (e-mail: a.cooper@bgs.ac.uk). \\ ${ }^{2}$ Civil Engineering Department, Trent University, Nottingham, NG1 4BU, UK.
}

\section{Published 1999 in Quarterly Journal of Engineering Geology, Vol 32, 305-310}

Please refer to the published document for the definitive article, there may be minor editorial changes made in the published document.

Keywords: England, gypsum, caves, sinkholes, subsidence

In the afternoon of Wednesday 23rd April 1997, a large subsidence crater opened up in front of a house on Ure Bank Terrace, on the northern outskirts of Ripon in North Yorkshire.

Overnight its sides collapsed inwards, so that the hole had doubled in size by the next morning (Fig. 1). The sinkhole was then $10 \mathrm{~m}$ in diameter, and was $5.5 \mathrm{~m}$ deep to a choke of debris covered by water $1 \mathrm{~m}$ deep. Its sudden appearance was of considerable concern to the occupants of the adjacent house, and the event was widely reported in the national press and media.

Subsidence had occurred at the Ure Bank site in previous years, but this collapse had rather more impact. Creeping movement of the soil towards the new hole meant that the adjacent house was destined for demolition. The event was the latest of a series of ground collapses that have occurred in and around the town of Ripon, at an average rate of about one per year. While they are little more than an inconvenience in farmland, they are potentially catastrophic where they are among buildings within the town.

The immediate cause of the Ure Bank subsidence was the downward movement of soil, drift and recent fill into actively expanding voids within the ground. Ultimately, it was caused by the partial collapse of a cave developed in Permian gypsum, which hereabouts extends 
between depths of 13 to about $45 \mathrm{~m}$ below ground level. There are two main beds of gypsum in the Ripon area. They lie within a Permian sequence of dolomite and limestone aquifers (Fig. 2), and these are overlain by the Sherwood Sandstone, which is the major aquifer in the region. All the Permo-Triassic bedrock units are cut through by the deeply entrenched, driftfilled, buried valley of the River Ure. This valley breaches the gypsum beds and the associated carbonate aquifers, freely allowing groundwater to cross the buried rockhead.

Gypsum dissolves very rapidly under flowing water, and normal river flow of about $1 \mathrm{~m} / \mathrm{s}$ can dissolve up to about one metre of gypsum per year. This rate of dissolution has been verified by many years of observation of the low cliffs (Fig. 3) along the River Ure at Ripon Parks, 3.5 km north of Ripon (James et al., 1981); around $6 \mathrm{~m}$ of undercutting of the cliff has taken place inside 9 years, before the face collapsed into the river.

These high rates of dissolution create a significant potential for the rapid development of cave systems where there is throughflow of groundwater within the beds of gypsum. Caves are known in gypsum throughout the world (Klimchouk et al., 1996). In dolomite/limestone and gypsum sequences, their most common morphology is a rectilinear maze in two dimensions, due to dissolutional opening of intersecting joints within a the gypsum confined between the sequences of other material. Such caves are normally formed by slowly moving water in the phreatic environment. Passage widths in these maze caves are generally only 1-3 $\mathrm{m}$, but in some mazes the gypsum bed has been removed across more than half of its area, in the manner of a pillar-and-stall mine. Larger linear cave passages are formed where groundwater flows are high (Fig. 4). In karst terraines of low relief, this can occur where melting glaciers provide massive flows of subglacial water; gypsum dissolution is not restricted by low temperatures (Waltham, 1994).

Caves have not yet been directly observed at Ripon, where most of the gypsum is beneath drift and below the water table, but interconnected cavities have been penetrated in boreholes. Small caves have been recorded in the Permian gypsum of Cumbria (Ryder \& 
Cooper, 1993), but here the gypsum is mainly confined between mudstone sequences. Water flow through the gypsum beds at Ripon is phreatic, and it is likely that any caves may have the form of a reticulate maze following the jointing pattern. An added factor at Ripon is the location of the site beneath the lateral margin ablation zone of the Vale of York glacier during the Devensian (Powell, et al., 1992, Cooper and Burgess, 1993). This may have encouraged larger cave passages to have been formed by meltwater.

The low mechanical strength of gypsum and its rapid dissolution along joint intersections combine to accelerate roof collapse within gypsum caves. Boreholes and exposures of similar rocks on the Durham coast and in Cumbria suggest that progressive upward stoping causes cavity migration above growing piles of debris, and ultimately creates breccia pipes which reach to rockhead. Collapse of the drift cover then creates surface depressions (Fig. 5); these are typical subsidence sinkholes (Culshaw \& Waltham, 1987), except that they differ from such sinkholes over limestone by being underlain by pipes of failed rock. These breccia pipes are well known in the Ripon area (Cooper, 1986, 1988, 1989). Whether individual pipes occur over joint intersections within maze caves or over larger passages within linear caves is open to debate. Both situations are recorded in comparable Russian gypsum caves in the Urals though the dissolution here is currently occurring by downward percolation of water in the vadose zone (Andrejchuk, et al., 1997).

The breccia pipes commonly reach through considerable thicknesses of solid rock above buried gypsum horizons, to create sinkholes in outcrops of insoluble rocks. One hole formed near Ripon station in 1834 and remains open today; it is $11 \mathrm{~m}$ across, and exposes solid Sherwood Sandstone in its sides down to a depth of at least $15 \mathrm{~m}$ (Fig. 6). A borehole near Ripon penetrated undisturbed drift and then solid rock to a depth of $24 \mathrm{~m}$, before descending through $4 \mathrm{~m}$ of unconsolidated cave sediments containing housebricks. There is no doubt that the gypsum caves are active, and are continuing to swallow material from above. 
The presence and threat of these sinkhole collapses is significant for urban development in the Ripon area, and provides special problems in site investigation. For example, if a typical site investigation borehole was drilled close to the rim of the station sinkhole (Fig. 6) it would prove solid red sandstone to a depth of over $15 \mathrm{~m}$, but only a few metres away there is a catastrophic subsidence. Complete assessment of the subsidence hazard at a site in Ripon could demand large numbers of closely spaced boreholes, which may have to reach depths of 60 or $70 \mathrm{~m}$. This is clearly an uneconomic proposition for most development. Geophysical surveys by microgravity (Patterson et al., 1995) or resistivity tomography have potential to identify anomalies in such areas and reduce the dependence on boreholes; however, these techniques have limitations in their depth penetration, their decrease of resolution with depth and the interference caused by the edge of the River Ure buried valley.

Only when a potential site has been fully investigated for subsidence hollows, breccia pipes and near-surface cavities can any form of development planning and design be considered for planning approval. This practice has been adopted by the local authority for development in the Ripon area using proforma stability/design suitability forms signed by a competent person for each new development (Thomson, et al., 1996). Difficulties can be caused when developers "plan and design” their structures before doing the ground investigation and are then unwilling to make changes in location or layout. Some ground in the Ripon area is just not suitable for development, and this can be inconvenient when the land has already been purchased speculatively. Though sinkholes and subsidence hollows have been mapped in the Ripon area, there is no pattern clearly enough recognisable to be useful in the prediction of future new sites of instability (Fig. 7). Throughout the town, the risk of sinkhole collapse must be accepted; individual events can be catastrophic, but the risk at most sites is extremely low. In a region prone to sinkholes, where event prediction is normally impossible, and sufficient site investigation is sensibly ruled out by cost, development should perhaps best proceed where risk is dispersed by an umbrella of adequate 
insurance. Sinkhole insurance is mandatory for all buildings in the Florida karst; it may need to be specified for land and structures within a specially defined zone around Ripon, where appropriate premium weighting, not refusal to provide cover, can reflect the risk.

Within the subsidence-prone area of Ripon, one precaution that is practicable is to avoid development on known sites of current or historical instability (Fig. 7). To these should be added exclusion zones around unstable features, and these may need to be $20 \mathrm{~m}$ or more wide; once a collapse has occurred dissolution can continue in the adjacent gypsum to cause another collapse, and in areas of thick drift, sinkholes can enlarge laterally as soils slump into narrow pipes. Because of the problems of liability it is also important not to leave known sites of potential instability within private gardens. House insurance covers the properties, garages and structures, but does not include the land; householders with subsidence hollows on their land could be held responsible for peripheral damage or threat to neighbouring property. Since these holes may be difficult, expensive or impossible to remediate, they are very undesirable to own.

There is no simple remediation for a major sinkhole collapse like that in Ure Bank (Fig. 1). Filling the subsidence crater merely creates temporary support for the sides of the collapse; long-term stability of the fill cannot be guaranteed, and many older holes that have been filled in this way have collapsed again. A subsidence sinkhole over limestone may be repaired by excavation to rockhead, placing chunkrock too large to enter the bedrock fissures, and backfilling to ground level. Many of the Ripon subsidences are in drift too deep to excavate to bedrock economically, and breccia pipes of large diameter can render this approach unreasonable. Geogrid mattresses sunk within the collapse zone or placed across at ground level can offer only temporary respite in an active sinkhole, before it is ultimately undermined.

Ground cavities associated with subsidence features in an active gypsum karst, may expand by dissolution at rates which are significant on an engineering time scale. 
Dissolutional removal of gypsum is generally at rates about 50-100 times faster than those for limestone. A fissure, breccia pipe or cave in gypsum, blocked by chunkrock, grout or a geogrid mattress, may be replaced by new dissolution voids within tens of years - causing renewed collapse and ground subsidence. Gypsum dissolution may even be enhanced where groundwater flow is concentrated around the margin of an engineered plug, thereby propogating new and spreading subsidence. Complete prevention of collapse in gypsum may only be possible by sealing from contact with groundwater, and this is probably impossible at Ripon where water circulates from the buried valley of the Ure. In addition any interuption of the natural groundwater flow may aggravate dissolution in the adjacent ground. An effective engineered response to subsidences and collapses in terraines of active gypsum karst, at Ripon or elsewhere, remains elusive.

Acknowledgements

The authors thank Mr T.J. Charsley and Mr M.G. Culshaw for constructive criticism of the manuscript. A.H.C. publishes with permission of the Director, British Geological Survey (NERC).

References

ANDREJCHUK, V., DOROFEEV, E. and LUKIN, V. 1997. Organ pipes in carbonatesulphate rocks at the Kungur Ice Cave, near Perm, Russia. Cave and karst science, Vol. 24, 101- 106.

COOPER, A H. 1986. Foundered strata and subsidence resulting from the dissolution of Permian gypsum in the Ripon and Bedale areas, North Yorkshire. 127-139 in HARWOOD, G M and SMITH, D B (Editors). The English Zechstein and related topics. Geological Society of London, Special Publication. No. 22. 
COOPER, A H. 1988. Subsidence resulting from the dissolution of Permian gypsum in the Ripon area; its relevance to mining and water abstraction. 387-390 in BELL, F G, CULSHAW, M G, CRIPPS, J C and LOVELL, M A (Editors) Engineering Geology of Underground Movements. Geological Society of London, Engineering Geology Special Publication No. 5.

COOPER, A H. 1989. Airborne multispectral scanning of subsidence caused by Permian gypsum dissolution at Ripon, North Yorkshire. Quarterly Journal of Engineering Geology, Vol. 22, 219-229.

COOPER, A H and BURGESS, I C. 1993 Geology of the country around Harrogate. Memoir of the British Geological Survey, Sheet 62 (England and Wales).

CULSHAW, M.G. \& WALTHAM, A.C. 1987. Natural and artificial cavities as ground engineering hazards. Quarterly Journal of Engineering Geology, Vol. 20, 139-150.

JAMES, A N, COOPER, A H and HOLLIDAY, D W. 1981. Solution of the gypsum cliff (Permian Middle Marl) by the River Ure at Ripon Parks, North Yorkshire. Proceedings of the Yorkshire Geological Society, Vol. 43, 433-450.

KLIMCHOUK, A., LOWE, D., COOPER, A. \& SAURO, U. 1996. Gypsum karst of the world. International Journal of Speleology, Vol. 25, Nos 3-4, 1-307.

RYDER, P F, \& COOPER, A H. 1993. A cave system in Permian gypsum at Houtsay Quarry, Newbiggin, Cumbria, England. Cave Science, Vol. 20, 23-28.

PATTERSON, D., DAVEY, J.C., COOPER, A.H. \& FERRIS, J.K. 1995. The application of microgravity geophysics in a phased investigation of dissolution subsidence at Ripon, Yorkshire. Quarterly Journal of Engineering Geology, Vol. 28, 83-94.

POWELL, J H, COOPER, A H and BENFIELD, A C. 1992. Geology of the country around Thirsk. Memoir of the British Geological Survey, Sheet 52 (England and Wales). 
THOMSON, A., HINE, P.D., GREIG, J.R. and PEACH, D.W. 1996. Assessment of subsidence arising from gypsum dissolution: Technical Report for the Department of the Environment. Symonds Travers Morgan, East Grinstead. 288pp.

WALTHAM, A.C. 1994. Gypsum caves of Pinega, Russia. International Caver, No. 10, 1522. 


\section{Figure captions}

FIG. 1. The new sinkhole at Ure Bank Terrace, Ripon, looking north-east. The hole formed in April 1997, and measured 10m across and 5.5m deep. It was caused by collapse over a cave formed in gypsum of Permian age. Photograph by Tony Waltham.

FIG. 2. Diagrammatic profile of the approximate sequence of beds in the vicinity of the sinkhole site at Ure Bank Terrace.

FIG. 3. River cliff developed in the Edlington Formation gypsum at Ripon Parks, 3.5km north of Ripon. This photograph was taken in 1980 when the face was undercut by about 1.5m. By August 1989 the undercut measured about 6m, and the full flow of the river passed through it, before the face collapsed some time later that year. Photograph by Anthony Cooper.

FIG. 4. Cave passage within a bed of Permian gypsum at Pinega, Russia. The cave was enlarged partly by subglacial or proglacial meltwater in an environment which may be compared to that of the Ripon area during the Devensian. Photograph by Tony Waltham.

FIG. 5. Subsidence sinkhole that formed on February 1st 1982 at Sharow, near Ripon. The hole was $12 \mathrm{~m}$ in diameter and up to $9.7 \mathrm{~m}$ deep. Photograph by Anthony Cooper.

FIG. 6. Vertical shaft that formed by a drop-out collapse in July 1834 near Ripon railway station. The cylindrical sinkhole is $14 \mathrm{~m}$ in diameter and $15 \mathrm{~m}$ deep with red Sherwood Sandstone exposed in its sides. Photograph by Anthony Cooper.

FIG. 7. The distribution of sinkholes and subsidence hollows (both shown in black) in the Ripon area, whose built up area is shown stippled. Dates of the subsidences are given where known, and the named sites are referred to in the text. 
FIG. 1. The new sinkhole at Ure Bank Terrace, Ripon, looking north-east. The hole formed in April 1997, and measured 10m across and 5.5m deep. It was caused by collapse over a cave formed in gypsum of Permian age. Photograph by Tony Waltham.

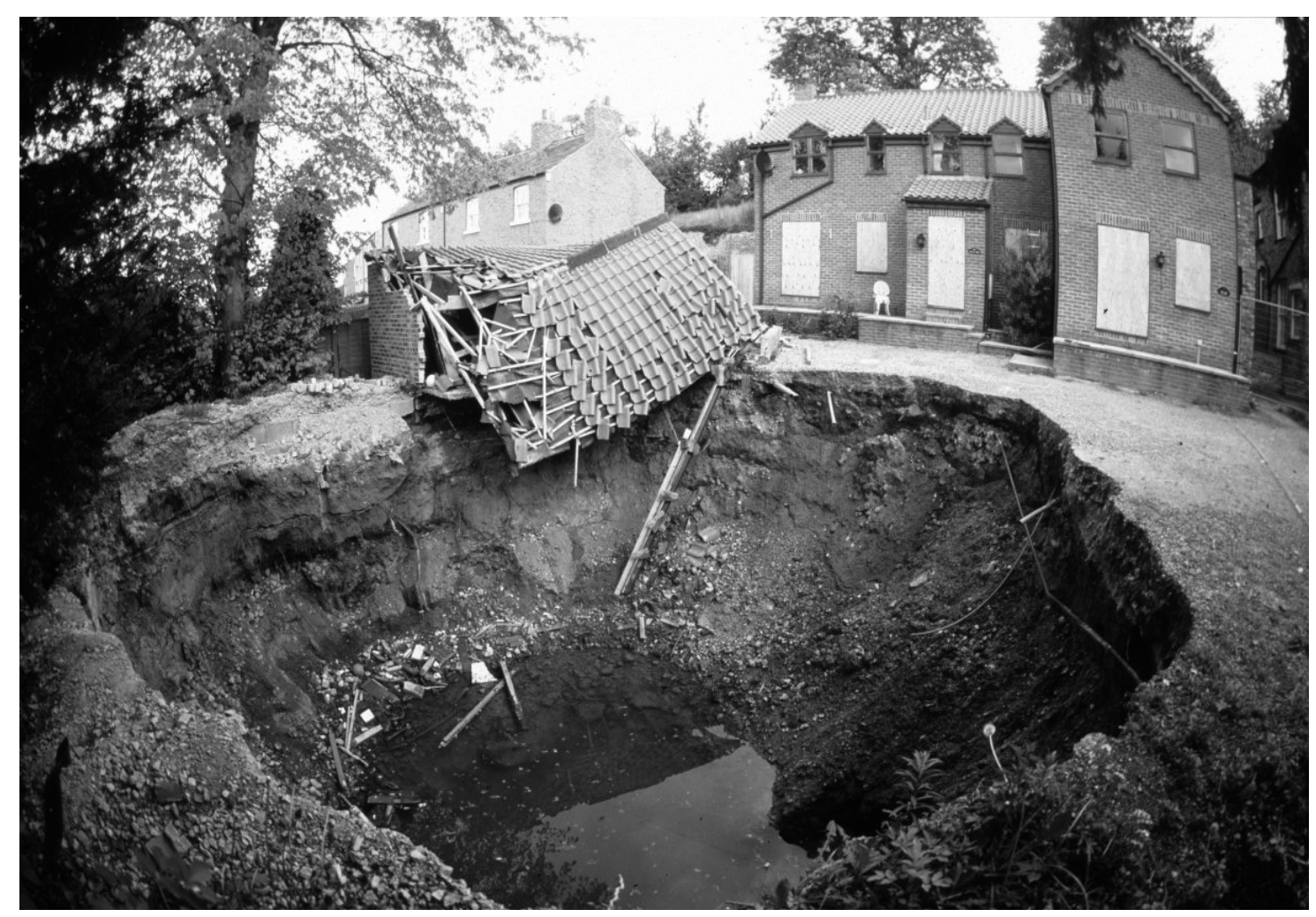


FIG. 2. Diagrammatic profile of the approximate sequence of beds in the vicinity of the sinkhole site at Ure Bank Terrace.

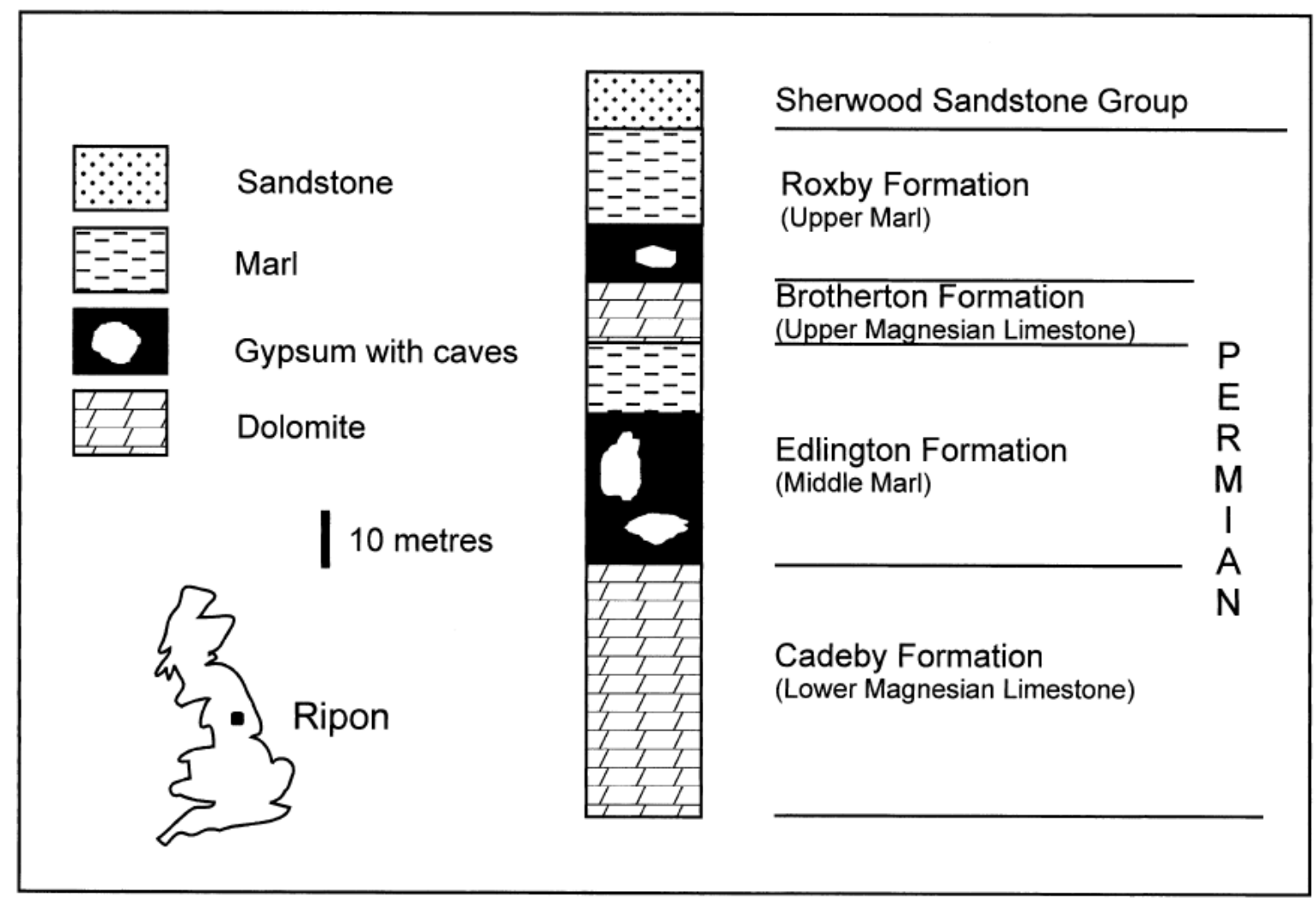


FIG. 3. River cliff developed in the Edlington Formation gypsum at Ripon Parks, 3.5km north of Ripon. This photograph was taken in 1980 when the face was undercut by about 1.5m. By August 1989 the undercut measured about 6m, and the full flow of the river passed through it, before the face collapsed some time later that year. Photograph by Anthony Cooper.

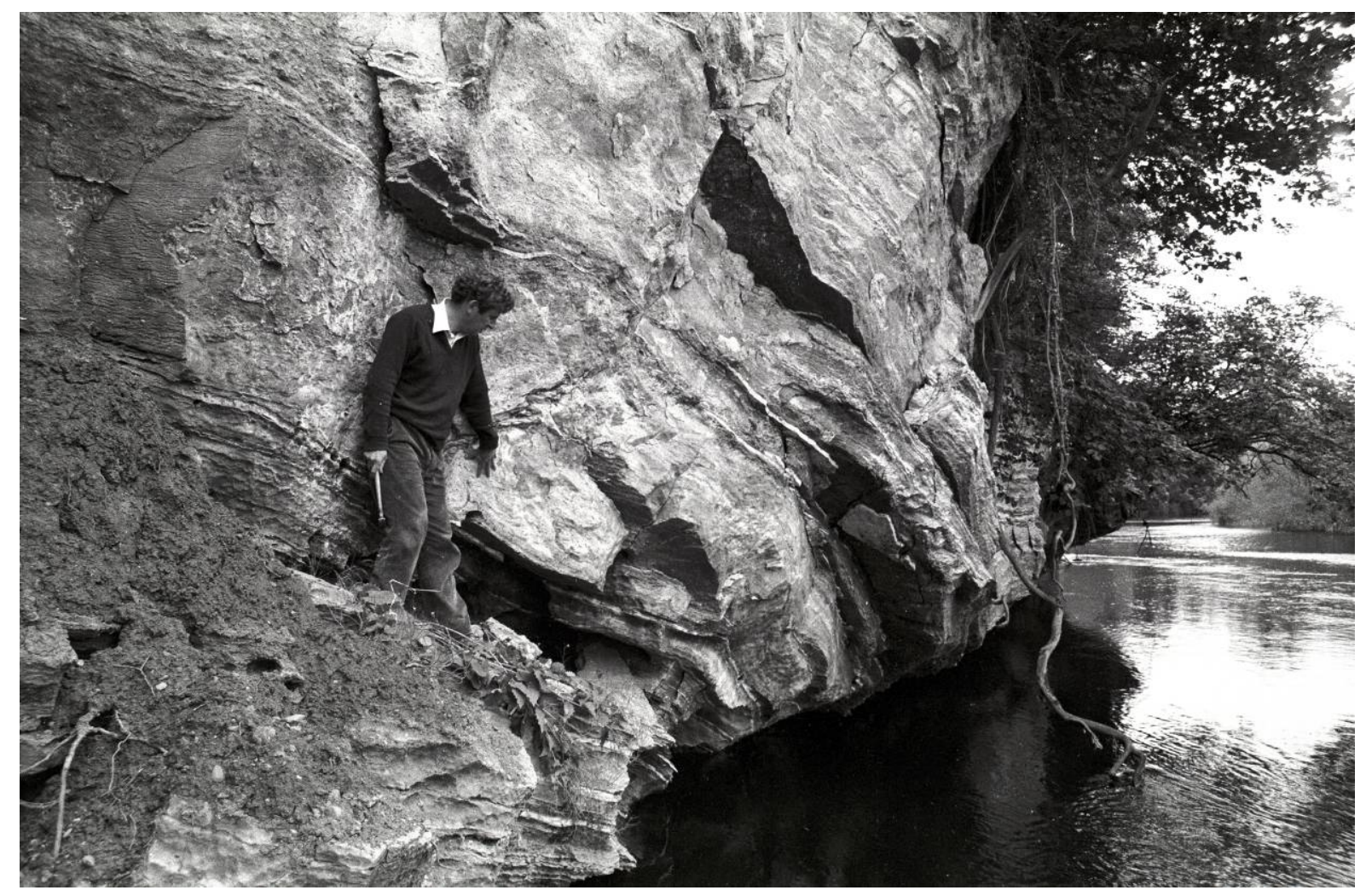


FIG. 4. Cave passage within a bed of Permian gypsum at Pinega, Russia. The cave was enlarged partly by subglacial or proglacial meltwater in an environment which may be compared to that of the Ripon area during the Devensian. Photograph by Tony Waltham.

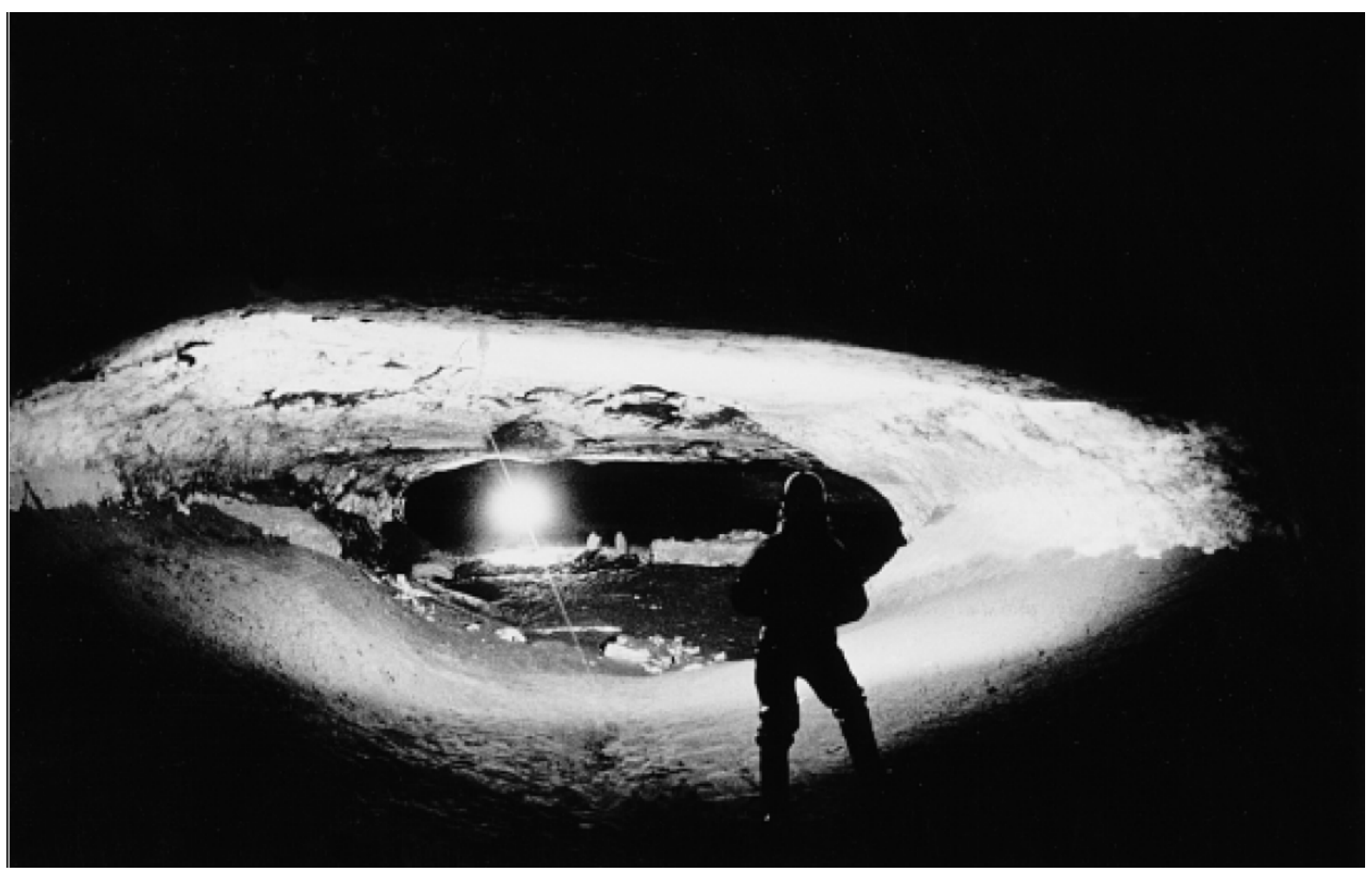


FIG. 5. Subsidence sinkhole that formed on February 1st 1982 at Sharow, near Ripon. The hole was $12 \mathrm{~m}$ in diameter and up to $9.7 \mathrm{~m}$ deep. Photograph by Anthony Cooper.

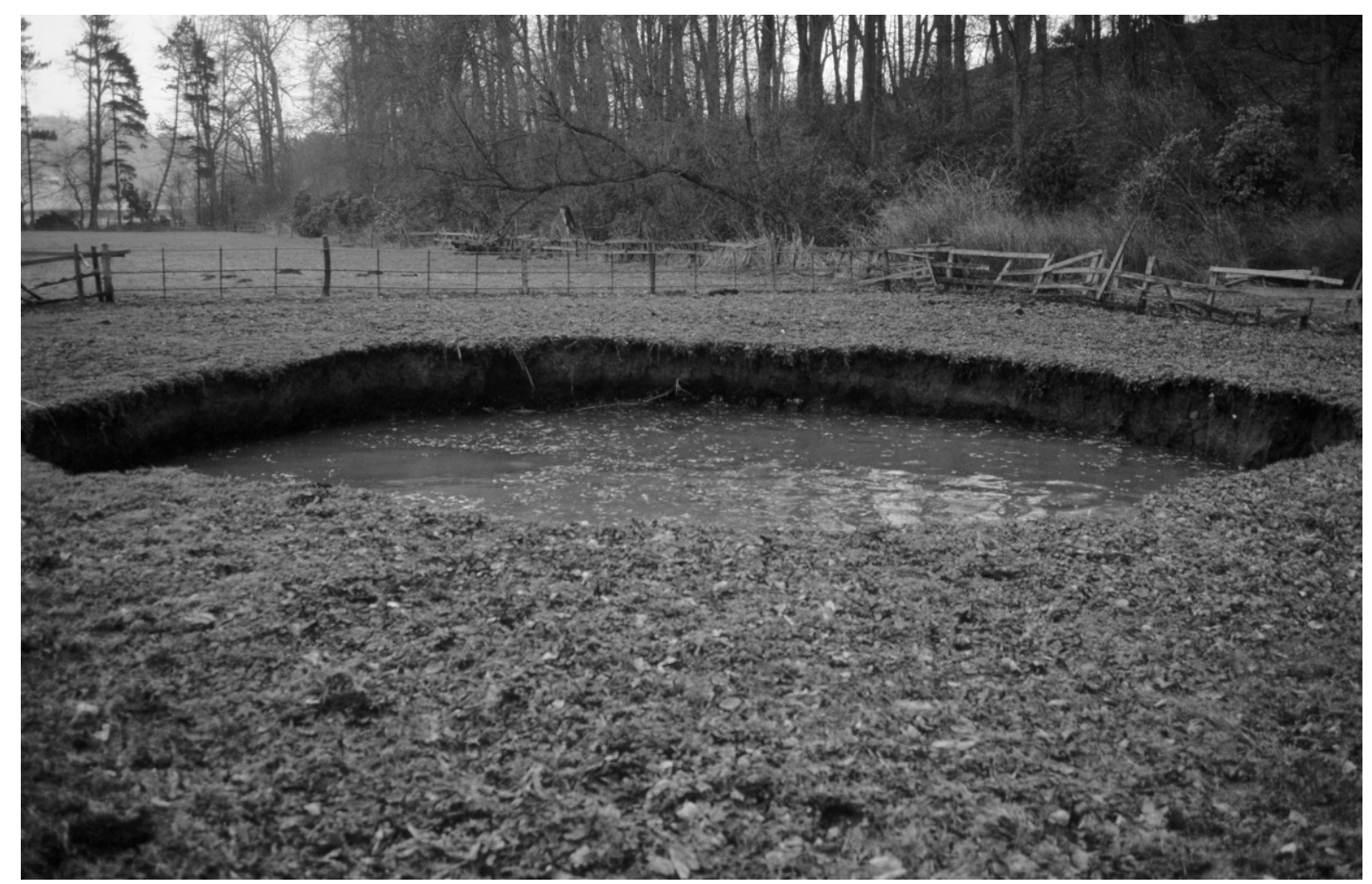


FIG. 6. Vertical shaft that formed by a drop-out collapse in July 1834 near Ripon railway station. The cylindrical sinkhole is $14 \mathrm{~m}$ in diameter and $15 \mathrm{~m}$ deep with red Sherwood Sandstone exposed in its sides. Photograph by Anthony Cooper.

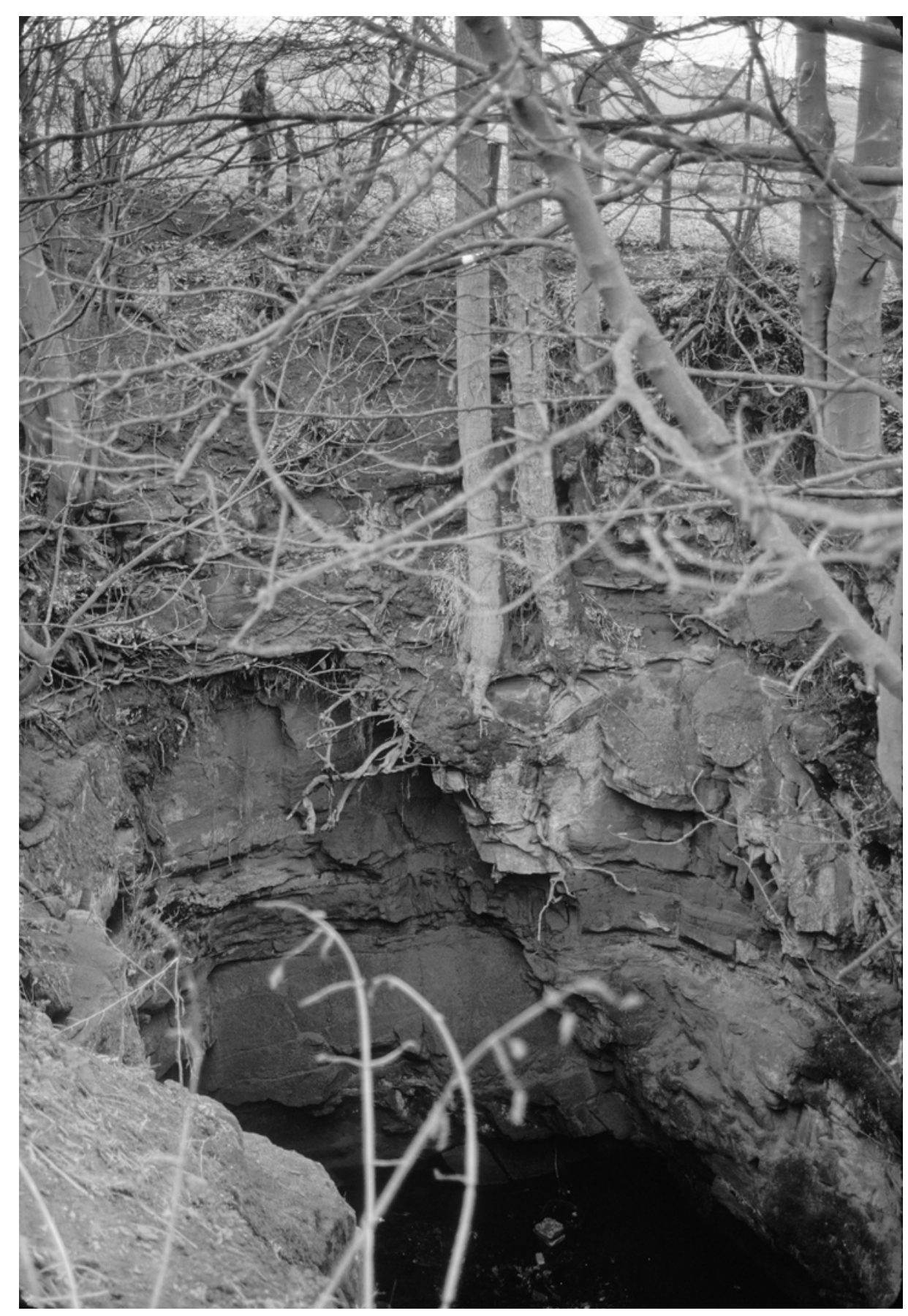


FIG. 7. The distribution of sinkholes and subsidence hollows (both shown in black) in the Ripon area, whose built up area is shown stippled. Dates of the subsidences are given where known, and the named sites are referred to in the text.

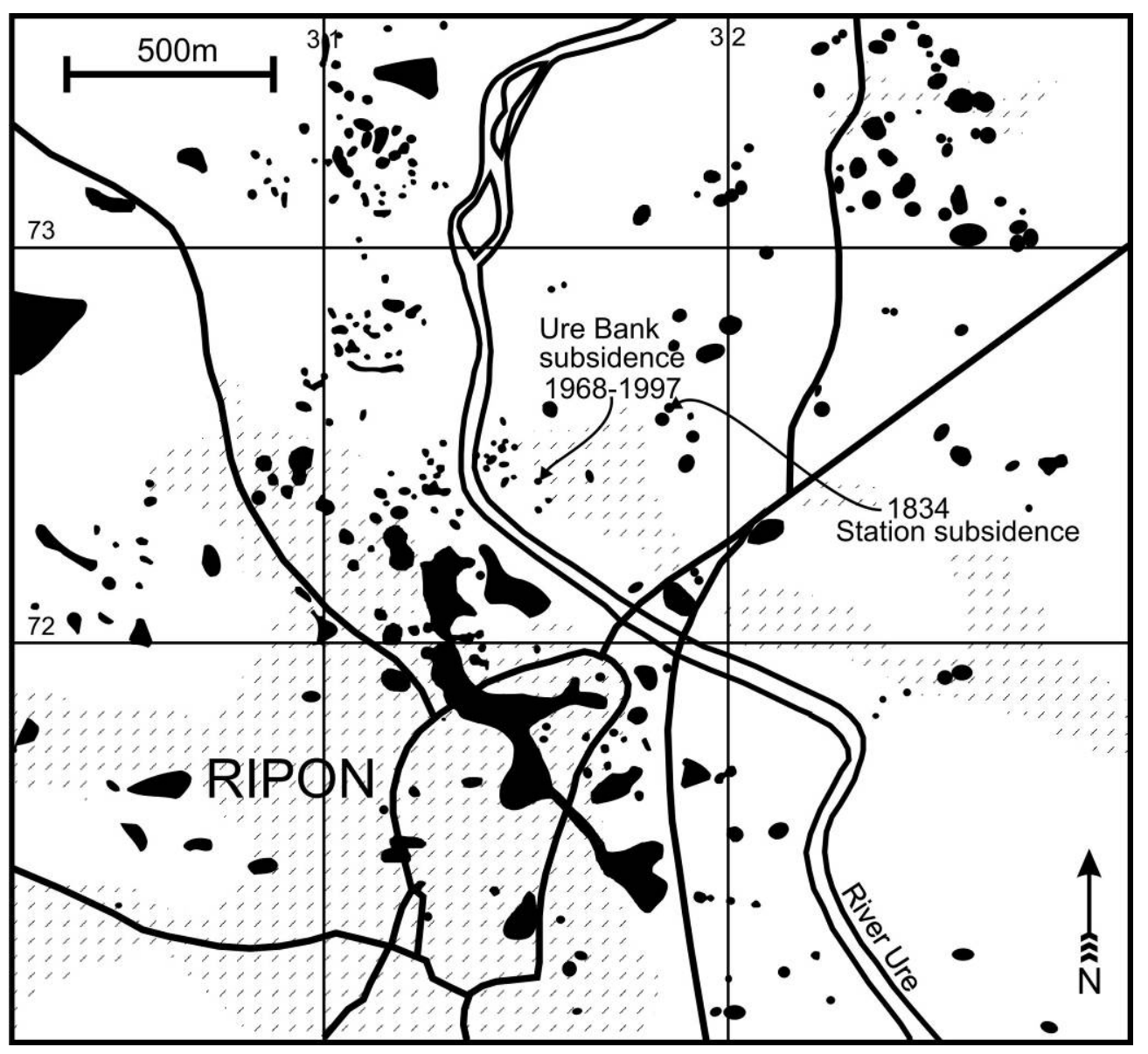

